\title{
Prevalence of rhinitis among 6 and 7-year old students in Fortaleza
}

\author{
Maria de Fátima G. de Luna ${ }^{1 *}$, Gilberto B. Fisher² ${ }^{2}$ João Rafael G. de Luna ${ }^{3}$, Marcelo G. C. da Silva ${ }^{4}$, Paulo César de Almel- \\ $\mathrm{DA}^{4}$, Daniela Chiesa ${ }^{5}$ \\ 'Pediatrician, Masters in Public Health. Doctorate student in Pneumology. Federal University of Rio Grande do Sul (UFRGS), Porto Alegre, RS, Brazil. \\ ${ }^{2}$ Physician, PhD in Pneumology Sciences. Responsible for the Respiratory Diseases discipline for the Post-Graduate in Pediatric Medicine course at UFRGS, Porto Alegre, RS, Brazil. \\ ${ }^{3}$ Medical Student at the Federal University of Ceará (UFC). Fortaleza, CE, Brazil. \\ ${ }^{4} \mathrm{PhD}$ in Public Health. Professor at the State University of Ceará (UECE), Fortaleza, CE, Brazil. \\ ${ }^{5}$ Physician, PhD Pneumology Sciences. Professor at the University of Fortaleza (Unifor), Fortaleza, CE, Brazil.
}

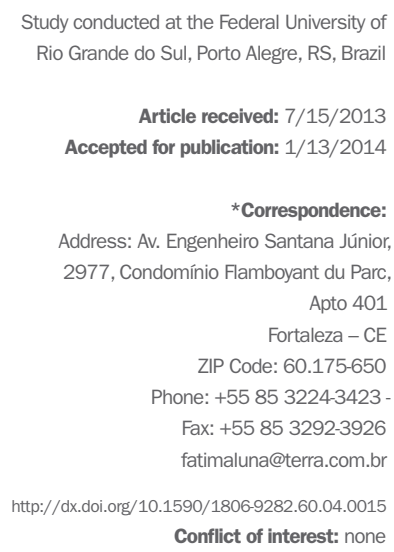

\section{SUMmARY}

Objective: to evaluate the prevalence of rhinitis symptoms among 6 and 7-year old schoolchildren in Fortaleza, Brazil.

Methods: a cross-sectional study using the rhinitis module of the ISAAC (International Study of Asthma and Allergies in Childhood) questionnaire. The sample included 2,020 students from public and private schools, in 2010.

Results: the prevalence of cumulative rhinitis, active rhinitis, allergic rhinoconjunctivitis and physician-diagnosed rhinitis was $49.9 \%, 42 \%, 15.4 \%$ and $28.1 \%$, respectively, being significantly more prevalent among private school students $(\mathrm{OR}=0.55$, 95CI: $0.46-0.66, \mathrm{p}<0.001$; OR $=0.50,95 \mathrm{CI}: 0.41-0.60, \mathrm{p}<0.001$; $\mathrm{OR}=0.67,95 \mathrm{CI}: 0.52-0.85, \mathrm{p}<0.001 ; \mathrm{OR}=0.15$, 95CI: $0.12-0.19, \mathrm{p}<0.001$, respectively), without differences between genders. Interference with daily activities was reported by $25.3 \%$, while $5.7 \%$ reported to be moderately or severely affected, without a difference between genders.

Conclusion: the prevalence of rhinitis symptoms and associated morbidity among 6-7-year old schoolchildren in Fortaleza was above the Brazilian average, with predominance among private school students, without difference between genders. It was observed that rhinitis was underdiagnosed in this population.

Uniterms: rhinitis, prevalence, morbidity, epidemiology, child.

\section{INTRODUCTION}

Allergic rhinitis is the most common chronic disease in children, and its prevalence has been increasing in many parts of the world, in recent decades, especially in developed countries. While not usually a serious illness, it reduces the patients' quality of life, causes sleep disorders, emotional problems, affects school performance, and presents frequent comorbidities, such as asthma and eczema. ${ }^{1-4}$

Knowingly, the manifestation of allergic diseases depends on the interaction between genetic and environmental factors. Genetic factors, while important, cannot justify per se the increases in prevalence, and it is likely that the environment has greater relevance, in this sense. ${ }^{5,6}$

The lack of a measurement method that is satisfactory and widely accepted has been an obstacle in the investigation of the prevalence and severity of asthma and rhinitis, limiting the relevance of spatial and temporal comparisons between populations. Thus, in 1991 the ISAAC (International Study of Asthma and Allergies in Childhood), protocol was developed, seeking to maximize the value of research on asthma, rhinitis and eczema in children and adolescents by promoting a standardized methodology to facilitate the international collaborative studies. ${ }^{\text {? }}$

The goals of the ISAAC, in its first phase, were to describe the prevalence and severity of asthma, rhinitis and eczema among children living in different regions of the world, and to make comparisons within and between countries and regions. Furthermore, it also aimed to obtain baseline measures to assess future trends in the prevalence and severity of these illnesses and provide a structure for future etiologic studies in genetics, lifestyle, healthcare and 
environmental factors that may affect these illnesses. In its second phase, it aimed at analyzing objective diagnostic measures used for asthma and allergies, comparing these measures between the different centers involved, in addition to exploring new hypotheses related to the development of these illnesses. In its third phase, it sought to assess trends in the prevalence of asthma, rhinitis and eczema in participants in phase I, adding new centers, which had not participated in this phase, and to identify possible factors related to these trends. ${ }^{7}$

The results from the ISAAC showed wide variation in the prevalence of asthma, rhinitis and eczema among different countries and among regions within the same country. 8

In Brazil, the results concerning the participation of several cities in phase III of the ISAAC study showed prevalence rates of rhinitis that ranged from 19.3\% (Itajaí, RJ) to 39.8\% (Salvador, BA), and rhinoconjunctivitis ranged from $10.3 \%$ (Aracajú, SE) to $17.4 \%$ (Salvador, BA), in the 6 and 7 age group. ${ }^{10}$ However, in Ceará, a population study on rhinitis in this age group, performed with this methodology, is not yet available. The present study sought to evaluate the prevalence of rhinitis symptoms among 6 and 7-year old school children, in Fortaleza.

\section{Methods}

This is a cross-sectional, descriptive, population-based study, involving 6 and 7-year old school children, from public and private schools, conducted from April to November 2010 in Fortaleza, Ceará, Brazil, using the ISAAC written questionnaire.

Fortaleza is located on a coastal plain, just below the equator, with latitude between $30^{\circ} 3^{\prime}$ and $4^{\circ} 30^{\prime}$ and an altitude of 15.49 meters. It has a length of $4,667.8 \mathrm{~km}^{2}$ and a population of 2,431,415 inhabitants. ${ }^{11}$ The annual average temperature varies between $26^{\circ} \mathrm{C}$ and $27^{\circ} \mathrm{C} .{ }^{12}$ The air quality is currently classified as regular, with relative humidity of around $82 \%{ }^{13}$ According to the 2010 census, $72.9 \%$ of the population earned less than twice the minimum wage. ${ }^{11}$

The city is divided into six administrative regions and the schools are aggregated by region. In 2009, the Department of Education of the State of Ceará ${ }^{14}$ registered 52,346 6 and 7-year old students, with a ratio of students from public and private schools of around 1:1.

Among the schools whose records indicated a number of not less than 50 students in the age range for the study, 25 were randomly selected, distributed among the six administrative regions. The proportion of 6 and 7 -year old children was maintained in each region, as was the proportion of these children in public and private schools, therefore optimizing the representativeness of the sample.

To collect the data we used the rhinitis module from the ISAAC written questionnaire, ${ }^{7}$ which recommends that the sample has 3,000 subjects for the prevalence and severity study, and that a sample size of 1,000 subjects would be sufficient for the prevalence study. This instrument emphasizes the reporting of symptoms unrelated to a cold or the flu, and was validated in Brazil by Vanna et al., ${ }^{15}$ and is made up of six items: 1 - sneezing, runny nose or nasal obstruction in the subject's lifetime (cumulative rhinitis); 2 - sneezing, runny nose or nasal obstruction in the last 12 months (active rhinitis); 3 - sneezing, runny nose or nasal obstruction accompanied by tearing or itchy eyes in the last 12 months (allergic rhinoconjunctivitis); 4 - month or months in which the nasal problems occurred in the last 12 months (this question, for which the respondent records the months of occurrence of symptoms, was named "month to month distribution of the symptoms"); 5 - interference of the nasal symptoms with daily activities (this question measures the morbidity / severity of symptoms) and 6 - rhinitis sometime in the subject's life (physician-diagnosed rhinitis).

The question from item 5 has four answers: never, slightly, moderately, and a great deal (severe rhinitis), and the last three were considered positive for purposes of the analysis. The difference between the prevalence of active rhinitis and diagnosed rhinitis was considered an "underdiagnosis of rhinitis."

3,346 questionnaires were distributed to 6 and 7-year old children, who took them home to be answered by parents or guardians and later returned to the teachers and collected by researchers and/or research assistants. The questionnaires were accompanied by a letter with explanations about the purpose of the research, in addition to a consent form, and were sent up to three times to those parents who did not return them within a week.

Data were processed using the SPSS - Statistical Package for the Social Sciences, version 15.0. The frequencies of positive responses to questions were obtained by considering the percentage of positive responses for each question in relation to the total number of valid questionnaires. For an analysis of possible associa- 
tions between variables, we used the $\mathrm{z}$ test for proportions, also estimating the odds ratio (OR) and confidence interval of $95 \%$ (95CI). The results of the tests were considered statistically significant, with $\mathrm{p}<$ 0.05 . The study was approved by the Research Ethics Committee of the State University of Ceará (Case $\mathrm{N}^{\mathrm{o}}$. 09554007-5, FR 31889).

\section{Results}

We obtained a return rate of $61.8 \%$ and response rate of $60.4 \%$, thus obtaining 2,020 valid questionnaires, 988 (48.9\%) of which were from males and $1,032(51.1 \%)$ of which were from females. A total of 997 (49.4\%) came from public schools and 1,023 (50.6\%) from private schools, thus maintaining a ratio of approximately 1:1 between these two groups of school children.

Table 1 shows the frequencies of rhinitis symptoms, stratified by gender and type of school. There were no significant differences between genders regarding the frequency of rhinitis symptoms or diagnosed rhinitis, and no significant difference between the two groups regarding how the symptoms affected their daily activities in the "moderately" and "a great deal (severe rhinitis)" categories. There was only a higher prevalence of male schoolchildren who reported no interference of rhinitis symptoms with daily activities, and a higher prevalence of female students who reported little interference of such symptoms with daily activities. We also observed a significant difference between the prevalence of active rhinitis and diagnosed rhinitis, indicating an underdiagnosis of the illness in this population.

The prevalence of cumulative rhinitis, current rhinitis, rhinoconjunctivitis and diagnosed rhinitis were significantly higher among students from private schools. It was also this group that reported the most hindrance with daily activities, due to rhinitis, in the "moderate" category, but it was among students from public schools that significantly predominated reports of daily activities being "greatly hindered by rhinitis" (severe rhinitis).

TABLE 1 Distribution of frequency and stratification of rhinitis symptoms according to gender and type of school, in a sample of 2,020 6 and 7-year old school children. Fortaleza, Ceará, Brazil, 2010

\begin{tabular}{|c|c|c|c|c|c|c|c|c|c|c|c|c|c|c|c|}
\hline \multirow[t]{3}{*}{ Symptoms } & \multirow{2}{*}{\multicolumn{3}{|c|}{ Frequency }} & \multicolumn{4}{|c|}{ Gender } & \multirow[t]{3}{*}{ OR (95Cl) } & \multirow[t]{3}{*}{$\mathbf{P}$} & \multicolumn{4}{|c|}{ Type of school } & \multirow[t]{3}{*}{ OR (95Cl) } & \multirow[t]{3}{*}{$P$} \\
\hline & & & & \multicolumn{2}{|c|}{$\begin{array}{l}\text { Male } \\
(n=988)\end{array}$} & \multicolumn{2}{|c|}{$\begin{array}{l}\text { Female } \\
(n=1032)\end{array}$} & & & \multicolumn{2}{|c|}{$\begin{array}{l}\text { Public } \\
(n=997)\end{array}$} & \multicolumn{2}{|c|}{$\begin{array}{l}\text { Private } \\
(n=1023)\end{array}$} & & \\
\hline & $\mathbf{n}$ & $\%$ & $(95 \mathrm{Cl})$ & n & $\%$ & n & $\%$ & & & $\mathbf{n}$ & $\%$ & n & $\%$ & & \\
\hline $\begin{array}{l}\text { Cumulative } \\
\text { rhinitis }\end{array}$ & 1029 & 49.9 & $(47.7-52)$ & 521 & 54.1 & 508 & 50.7 & $1.1(0.9-1.3)$ & 0.13 & 433 & 44.9 & 596 & 59.4 & $0.5(0.4-0.6)$ & $<0,001$ \\
\hline Active rhinitis & 849 & 42 & $(39.8-44.1)$ & 432 & 85.7 & 417 & 84.2 & $1.1(0.7-1.5)$ & 0.51 & 335 & 33.6 & 514 & 50.2 & $0.5(0.4-0.6)$ & $<0.001$ \\
\hline Rhinoconj & 312 & 15.4 & $(13.8-16.9)$ & 166 & 38.1 & 146 & 34.7 & $1.1(0.8-1.5)$ & 0.29 & 128 & 12.8 & 184 & 18 & $0.6(0.5-0.8)$ & 0.001 \\
\hline \multicolumn{16}{|l|}{$\begin{array}{l}\text { Interference } \\
w / \text { activities }\end{array}$} \\
\hline Never & 356 & 17.6 & $(15.9-19.2)$ & 198 & 44.4 & 158 & 37.2 & $1.3(1.02-1.7)$ & 0.03 & 140 & 40.1 & 216 & 41.7 & $1.06(0.8-1.4)$ & 0.64 \\
\hline Slightly & 397 & 19.6 & $(17.8-21.3)$ & 186 & 42 & 211 & 50 & $0.7(0.5-0.9)$ & 0.01 & 161 & 46.1 & 236 & 45.6 & $0.9(0.7-1.2)$ & 0.86 \\
\hline Moderately & 76 & 3.8 & $(2.9-4.6)$ & 38 & 8.6 & 38 & 9 & $0.9(0.5-1.5)$ & 0.84 & 23 & 6.6 & 53 & 10.2 & $1.6(0.9-2.6)$ & 0.06 \\
\hline A great deal & 38 & 1.9 & $(1.71-2.08)$ & 22 & 5 & 16 & 3.8 & $1.3(0.6-2.5)$ & 0.39 & 25 & 7.2 & 13 & 2.5 & $0.3(0.1-0.6)$ & 0.001 \\
\hline $\begin{array}{l}\text { Diagnosed } \\
\text { rhinitis }\end{array}$ & 568 & 28.1 & $(26.1-30)$ & 289 & 30.8 & 279 & 28.2 & $1.1(0.9-1.3)$ & 0.20 & 109 & 11.6 & 459 & 46.1 & $0.15(0.12-0.19)$ & $<0.001$ \\
\hline
\end{tabular}


Table 2 shows that, among children who reported a greater interference with daily activities, due to symptoms ("moderate" and "high" categories), there were more reports of diagnosed rhinitis, compared to those with less interference ("never" and "slightly" categories).

Figure 1 shows the monthly distribution pattern of nasal symptoms, for the past 12 months. We opted to add data from a previous study ${ }^{16}$ here, which refers to the monthly distribution pattern of nasal symptoms among 13 to 14-year old adolescents. The study was conducted using the same methodology. Thus, one can observe the patterns of seasonality of nasal symptoms in these two age groups. We notice that, in both age groups, these symptoms maintain certain continuity in our setting, with a seasonal peak observed in August, configuring an increasing trend from January to July, and a downward trend, from August to December.

\section{Discussion}

The prevalence of cumulative rhinitis, active rhinitis, allergic rhinoconjunctivitis and diagnosed rhinitis were, respectively, $49.9 \%, 42 \%, 15.4 \%$ and $28.1 \%$, predominan-

TABLE 2 Distribution of the prevalence of diagnosed rhinitis according to the symptoms related to the morbidity of rhinitis, in a sample of 2,020 6 and 7-year old school children. Fortaleza, Ceará, Brazil, 2010

\begin{tabular}{|c|c|c|c|c|c|c|c|c|c|}
\hline \multirow[t]{3}{*}{ Diagnosed rhinitis } & \multicolumn{8}{|c|}{ Interference of the symptoms with daily activities } & \multirow[t]{3}{*}{$\mathbf{P}$} \\
\hline & \multicolumn{2}{|c|}{ Never } & \multicolumn{2}{|c|}{ Slightly } & \multicolumn{2}{|c|}{ Moderately } & \multicolumn{2}{|c|}{ A great deal } & \\
\hline & $\mathbf{n}$ & $\%$ & $\mathbf{n}$ & $\%$ & $n$ & $\%$ & $\mathbf{n}$ & $\%$ & \\
\hline Yes & 130 & 37.8 & 206 & 54.2 & 49 & 66.2 & 20 & 60.6 & \multirow[t]{2}{*}{$<0.001^{*}$} \\
\hline No & 214 & 62.2 & 174 & 45.8 & 25 & 33.8 & 13 & 39.4 & \\
\hline
\end{tabular}

* Statistical significance. Z-test used for proportions.

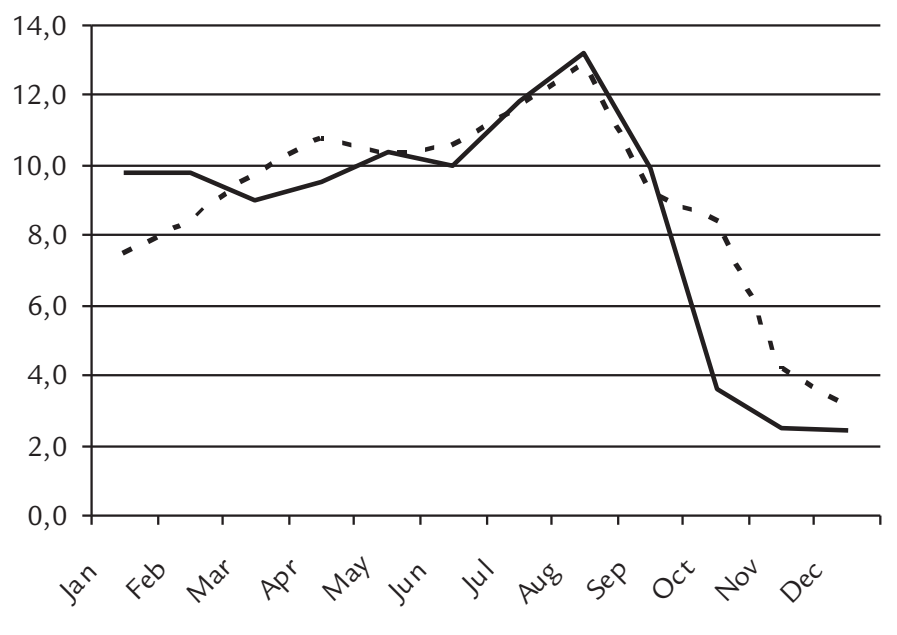

6 and 7-year old children (2010)

- - 13 and 14-year old adolescents $(2006 / 2007)$

FIGURE 1 Month-to-month distribution of symptoms (month in which nasal symptoms occurred, in the last twelve months) in 6 and 7-year old children in 2010, and the month-to-month distribution of these symptoms observed in 13 and 14 -year old adolescents, in a previous study. ${ }^{15}$ 
tly among children from private schools, and with no difference between genders. Interference with daily activities was reported by $25.3 \%$, while $5.7 \%$ reported to be moderately or severely affected, without a difference between genders.

Questionnaires have been the most commonly used tools in epidemiological surveys, offering several advantages, among them the possibility of being self-applicable, thus eliminating the interviewer bias. However, a concern that we have, when conducting research based on questionnaires, is related to the ability of the population to understand the issues and provide appropriate responses. Facilitating this process, the ISAAC written questionnaire is presented with objective, defined and easily understandable questions. It has been validated in several countries and has been applied worldwide, allowing for valid comparisons of the prevalence of asthma and allergies among different cities and countries. Also validated in Brazil, the rhinitis component proved to be reproducible and suitable for distinguishing children and adolescents with and without rhinitis. ${ }^{7,15}$

The rate of return for questionnaires may influence the results, and in this study, the rate of return was similar to those found in other Brazilian cities that have investigated rhinitis and/or asthma in children in the same age group and using the ISAAC protocol, such as Curitiba $(58 \%)^{17}$ and the western region of São Paulo $(65.7 \%),{ }^{18}$ and also similar to international studies such as the one by Sánchez-Lerma et al, in Spain (60.6\%). ${ }^{19}$ In phase I of the ISAAC, the return indices for questionnaires distributed ranged from $60 \%$ to $100 \%$, being highest among adolescents. ${ }^{20}$

In this study, the prevalence of nasal symptoms was shown to be as high as in other regions of the world. The rate of cumulative rhinitis was similar to that found in Salvador, Brazil (45.2\%), in Mexico City, Mexico (49.4\%) and San Salvador, El Salvador (49.9\%), in phase III of the ISAAC. ${ }^{3,10}$ The rate of active rhinitis was shown to be above the national average $(25.6 \%)$ and was similar to that observed in Salvador, Brazil (40.1\%), in phase III of the ISAAC..$^{10}$ It was also similar to that recorded in a previous study (43.2\%) involving 13 to 14 -year old adolescents, in Fortaleza. ${ }^{16}$ Internationally, results were similar to those found in Havana, Cuba (39.8\%), São Salvador, El Salvador (41.8\%), Bangkok, Thailand (43.4\%), and equal to the rate found in Taipei, Taiwan (42\%). They were lower than results found in Mexico City (3), Mexico (46.6\%) - which had the highest rate recorded in Latin America for this age group. ${ }^{3}$
The prevalence of allergic rhinoconjunctivitis in the sample studied was within the values found in a study involving several Brazilian cities where the rate ranged from $10.3 \%$ (Aracaju) to $17.4 \%$ (Salvador), and only a little above average for these cities. ${ }^{10}$ It was also equal to the rate found in Barranquilla, Colombia (15.4\%) and similar to that found in Bogota (15.6\%), Colombia, ${ }^{3}$ for this age group. In phase III of the ISAAC, the prevalence of rhinoconjunctivitis varied between regions, from $4.2 \%$ in the Indian Subcontinent, to $12.7 \%$ in Latin America, with a global average of $8.5 \%$, but variations were significant among the centers and there was no consistent regional pattern. The lowest prevalence of rhinoconjunctivitis was found in parts of Eastern Europe, and Southern and Central Asia. A high prevalence was reported from the centers of several regions, not geographically related, such as the rate found in Taipei, Taiwan, in the Asia-Pacific region (24.2\%) and in Caracas, Venezuela, in Latin America $(20.4 \%)^{3}$

It is believed that environmental factors are largely responsible for the differences in rates of allergic disorders within and across countries and regions. They are probably related to the lifestyle of people and families, such as socioeconomic status, dietary habits, early exposure to infections, growing up in rural surroundings, family size and exposure to airborne allergens, since climate change, the degree of alertness and recognition of the illness or management of symptoms certainly influence these differences as well. ${ }^{3,5,6}$

The morbidity rate for rhinitis was also high in the population studied, since $25.3 \%$ of children reported that the symptoms had some degree of interference with their daily activities. This rate was above the national average (17.1\%) and the average found in the Northeast (18.5\%), remaining close to the rate found in Salvador (26\%), in phase III of the ISAAC study, ${ }^{10}$ which is similar to the pattern observed in a previous study involving 13 to 14 -year old adolescents in Fortaleza. ${ }^{16}$

Severe rhinitis (which affected daily activities "a great deal") was also above the national average (1.3\%) and was predominant among children in public schools. That was similar to the rate found in Western São Paulo $(1.9 \%),{ }^{10}$ and internationally, this rate ranged from $0 \%$, such as in Barcelona, Spain, to $3 \%$ in Managuan, Nicaragua. ${ }^{3}$ The rates of severe rhinitis tend to be higher in low and middle income countries, and may be partly related to management of the illness, including the non-availability of drugs for rhinitis and asthma, especially inhaled corticosteroids. $^{3}$ 
The underdiagnosis of rhinitis observed in this population is consistent with research conducted in Europe, involving Belgium, France, Germany, Italy, Spain and the UK, which showed that among patients with allergic rhinitis confirmed by researchers, $45 \%$ had not reported a previous medical diagnosis of rhinitis. ${ }^{21}$ The answer to the question "have you ever had rhinitis in your life?" depends on having been diagnosed with rhinitis, understanding it and having a recollection of it, and may be influenced by cultural factors that can affect the perception of symptoms, access to services, formulation of diagnoses, understanding of an illness and its treatment, since the morbidity/severity of symptoms also influences this response. ${ }^{16,22,23}$ Furthermore, since the symptoms are quite bearable by patients, the illness is usually highly underestimated by physicians, patients and family members. ${ }^{23,24}$ Therefore, we observed, in this study, that there was less parental awareness, with respect to the diagnosis of rhinitis, among those whose children had milder symptoms, with little or no hindrance of daily activities. Moreover, the rate of diagnosed rhinitis was significantly lower among children in public schools - where supposedly the poorest children who have the poorest access to health services are concentrated - which certainly contributed to severe rhinitis being prominent in this group.

There was a predominance of nasal symptoms among the group of children from private schools, in this population. In the epidemiology of allergic illnesses, the presence of a socioeconomic gradient has been observed, with a higher prevalence of allergic rhinitis and eczema among children and adults from families with higher purchasing power. ${ }^{6}$ Data from the present study is also consistent with that found in Brasilia, in an ISAAC study, which reported a higher prevalence of rhinitis symptoms among adolescents living in areas with a higher socioeconomic level, ${ }^{25}$ and supports the hygiene hypothesis, which interprets the variation in risk for allergic illnesses as a reflection of different exposures to infectious agents early in life. ${ }^{6}$

We noted, in this study, that the symptoms maintain some continuity, especially in the first half of the year when the rainy season occurs in Fortaleza and when we also observed a higher incidence of respiratory infections. Rates of symptoms fall in the period from October to December. It is assumed, therefore, that some of the symptoms reported in the first half of the year indicate an infectious origin. It is observed that a peak in nasal symptoms occurs in August, which seems to correspond, to a certain extent, to the period of pollination of the ca- shew tree, a plant that grows in abundance in Fortaleza and whose flowering, in the common type, begins in July. ${ }^{26}$ There are no known studies evaluating whether there is a relationship between this pollination and the incidence of allergic rhinitis in our setting, but at least two studies suggest a relationship between the period of when the cashew tree (Anacardium occidentale) flowers and the increased number of cases of allergic asthma. ${ }^{27,28}$ Accordingly, one can assume that the symptoms reported in this period indicate a predominantly atopic origin.

As for the seasonal variations of the nasal symptoms, which is a phenomenon that is already recognized, the answers may vary and respondents may have better recollection of symptoms that occurred more recently, albeit lighter, and have less recollection of symptoms that occurred a few months ago, which may favor biases in the evaluation of the month-to-month distribution of symptoms. ${ }^{29}$ However, we observed, in the present study, that the distribution pattern of symptoms was very similar to that found in a previous study, involving 13 to 14 -year old adolescents in Fortaleza, including the peak observed in August, ${ }^{16}$ suggesting that there may indeed be a pollinic period in Fortaleza, which would be from July to September.

\section{Conclusion}

The prevalence of rhinitis symptoms and associated morbidity among 6 and 7-year olds living in Fortaleza was shown to be above the national average, with a predominance in the group from private schools, and with no difference between genders; increasing, from January to July, and decreasing, from August to December. The prevalence of symptoms of allergic rhinoconjunctivitis was only slightly higher than the national average. The study also showed that rhinitis is underdiagnosed in this population. The results provide a warning to healthcare leaders and planners invest in the quality of primary care focused on the controlling this illness, remembering that adequate control of rhinitis offers a window of opportunity for the prevention of asthma. However, further epidemiological studies are needed, locally, to confirm these findings and to clarify the risk factors that may be determining the high prevalence of the illness among us.

\section{Resumo}

Prevalência de rinite em escolares de 6 e 7 anos de Fortaleza. 
Objetivo: avaliar a prevalência de sintomas de rinite em crianças de 6 e 7 anos de idade, em Fortaleza.

Métodos: foi aplicado o questionário ISAAC (International Study of Asthma and Allergies in Childhood), módulo rinite, em estudo de desenho transversal de base populacional, com amostragem probabilística de 2.020 escolares de escolas públicas e privadas, em 2010.

Resultados: a prevalência de rinite cumulativa, rinite ativa, rinoconjuntivite alérgica e rinite diagnosticada foi, respectivamente, 49,9, 42, 15,4 e 28,1\%, com predomínio de forma significativa entre as crianças das escolas particulares $(\mathrm{RC}=0,55$, IC95\%: 0,46 a 0,66, $\mathrm{p}<0,001 ; \mathrm{RC}=0,50$, IC95\%: 0,41 a 0,60, p < 0,001; RC = 0,67, IC95\%: 0,52 a $0,85, \mathrm{p}<0,001 ; \mathrm{RC}=0,15$, IC95\%: 0,12 a 0,19, $\mathrm{p}<0,001$, respectivamente), e sem diferença entre os gêneros. Interferência dos sintomas com as atividades diárias foi relatada por $25,3 \%$ dos pesquisados, e $5,7 \%$ relataram ser moderada ou intensamente afetados, sem diferença entre os gêneros.

Conclusão: a prevalência de sintomas de rinite e da morbidade associada, entre crianças de 6 e 7 anos de idade, em Fortaleza, mostrou-se acima da média nacional, com predomínio no grupo das escolas privadas, e sem diferença entre os gêneros. Observou-se também que rinite é subdiagnosticada entre as crianças de 6 e 7 anos de idade, em Fortaleza.

Unitermos: rinite; prevalência; morbidade; epidemiologia; criança.

\section{ACKNOWLEDGements}

The authors thank the National Technological and Scientific Development Council - CNPq - which gave financial support for this research to be carried out (Notice MCT/CNPq/CT-Health n 54/2009 - Respiratory Diseases in Childhood).

\section{References}

1. Bousquet J, Khaltaev N, Cruz AA, Denburg J, Fokkens WJ, Togias A, et al. Allergic Rhinitis and its Impact on Asthma (ARIA) 2008 update (in collaboration with the World Health Organization, GA(2)LEN and AllerGen). Allergy. 2008;63(Suppl 86):8-160.

2. Orfali RL, Shimizu MM, Takaoka R, Zaniboni MC, Ishizaki AS, Costa AA, et al. Atopic dermatitis in adults: clinical and epidemiological considerations. Rev Assoc Med Bras. 2013;59(3):270-5.

3. Ait-Khaled N, Pearce N, Anderson HR, Ellwood P, Montefort S, Shah J; ISAAC Phase Three Study Group. Global map of the prevalence of symptoms of rhinoconjunctivitis in children: The International Study of Asthma and Allergies in Childhood (ISAAC) Phase Three Allergy. 2009;64(1):123-48.

4. Teldeschi ALG, Sant'Anna CC, Aires VLT. Prevalência de sintomas respiratórios e condições clínicas associadas à asma em escolares de 6 a 14 anos no Rio de Janeiro. Rev Assoc Med Bras. 2002;48(1):54-9.
5. Von Mutius E. $99^{\text {th }}$ Dahlem Conference on Infection, Inflammation and Chronic Inflammatory Disorders: farm lifestyles and the hygiene hypothesis. Clin Exp Immunol. 2010;160(1):130-5

6. Strachan DP. Family size, infection and atopy: the first decade of the "hygiene hypothesis". Thorax. 2000;55(Suppl 1):S2-10.

7. International Study of Asthma and Allergies in Childhood - ISAAC. Auckland: International Study of Asthma and Allergies in Childhood. [cited 2009 June 10]. International Study of Asthma and Allergies in Childhood - Manual. Available from: http://isaac.auckland.ac.nz/phases/phaseone/ phaseonemanual.pdf

8. Asher MI. Recent perspectives on global epidemiology of asthma in childhood. Allergol Immunopathol (Madr). 2010;38(2):83-7.

9. Björkstén B, ClaytonT, Ellwood P, Stewart A, Strachan D. ISAAC Phase III Study Group. Worldwide time trends for symptoms of rhinitis and conjunctivitis: Phase III of the International Study of Asthma and Allergies in Childhood. Pediatr Allergy Immunol. 2008;19(2):110-24.

10. Solé D, Wandalsen GF, Camelo-Nunes IC, Naspitz CK; ISAAC - Brazilian Group. Prevalence of symptoms of asthma, rhinitis, and atopic eczema among Brazilian children and adolescents identified by the International Study of Asthma and Allergies in Childhood (ISAAC) - Phase 3. J Pediatr (Rio J). 2006;82(5):341-6.

11. Instituto Brasileiro de Geografia e Estatística. IBGE. Ministério do Planejamento, Orçamento e Gestão. Censo 2010. [cited 11 Jan 2011]. Available from: http://www.censo2010.ibge.gov.br

12. Fundação Cearense de Meteorologia e Recursos Hídricos. Fortaleza: Governo do Estado do Ceará. [cited 17 April 2011]. Available from: http://www. funceme.br.

13. Superintendência Estadual do Meio Ambiente - SEMACE. Fortaleza: Governo do Estado do Ceará. [cited 17 April 2011]. Available from: http://www.semace. ce.gov.br/.

14. Estado do Ceará. Secretaria da Educação. Matrícula das Escolas Públicas e Privadas de Fortaleza por Regional, Rede, Código, Idade e Série em 2009. [mensagem pessoal]. Mensagem recebida por: fatimaluna@terra.com.br. $5 / 18 / 09$.

15. Vanna AT, Yamada E, Arruda LK, Naspitz CK, Solé D. International Study of Asthma and Allergies in Childhood: validation of the rhinitis symptom questionnaire and prevalence of rhinitis in schoolchildren in São Paulo, Brazil. Pediatr Allergy Immunol. 2001;12(2):95-101.

16. Luna MF, Almeida PC, Silva MG. Prevalência de sintomas de rinite em adolescentes de 13 e 14 anos avaliada pelo método ISAAC, na cidade de Fortaleza. Rev Bras Alergia Imunopatol. 2009;32(3):106-11.

17. Ferrari FP, Rosário, NA, Ribas LFO, Callefe LG. Prevalência de asma em escolares de Curitiba projeto ISAAC. J Pediatr (Rio J). 1998;74(4):299-305.

18. Lima RG, Pastorino AC, Casagrande RRD, Sole D, Leone C, Jacob CMA. Prevalence of asthma, rhinitis and eczema in 6- 7 years old students from the western districts of São Paulo City, using the standardized questionnaire of the "International Study of Asthma and Allergies in Childhood" (ISAAC)Phase IIIB. Clinics. 2007.62(3):225-34.

19. Sánchez-Lerma B, Morales-Chirivella FJ, Peñuelas I, Blanco Guerra C, Mesa Lugo F, Aguinaga-Ontoso I, et al. High prevalence of asthma and allergic diseases in children aged 6 and 7 years from the Canary Islands: The International Study of Asthma and Allergies in Childhood. J Investig Allergol Clin Immunol. 2009;19(5):383-90.

20. The International Study of Asthma and Allergies in Childhood (ISAAC) Steering Committee. Worldwide variations in the prevalence of wheezing and asthma symptoms: The International Study of Asthma and Allergies in Childhood (ISAAC). Eur Resp J. 1998;12(2):315-35

21. Bauchau V, Durham SR. Prevalence and rate of diagnosis of allergic rhinitis in Europe. Eur Respir J 2004;24(5):758-64.

22. Enarson DA, Ait-Khaled N. Cultural barriers to asthma management. Pediatr Pulmonol. 1999;28(4):297-300.

23. Didier A, Chanal I, Klossek JM, Mathieu J, Bousquet J. La rhinite allergique: le point de vue du patient. Rev Fr Allergol. 1999;39:171-85.

24. Associação Brasileira de Alergia e Imunopatologia, Associação Brasileira de Otorrinolaringologia e Cirurgia Cérvico-facial, Sociedade Brasileira de Pediatria e Academia Brasileira de Rinilogia. II Consenso Brasileiro sobre Rinites 2006. Rev Bras Alerg Imunopatol. 2006;29(1):29-58.

25. Borges WG, Burns DAR, Felizola MLBM, Oliveira BA, Hamu CS, Freitas VC. Prevalência de rinite alérgica em adolescentes do Distrito Federal: comparação entre as fases I e III do ISAAC. J. Pediatr (Rio J) 2006;82(1):137-43. 
Barros LM, Paiva JR, Crisóstomo JR, Cavalcanti JJV. Hibridação de caju. [cited 14 June 2013]. Available from: http://www.ceinfo.cnpat.embrapa.br/ arquivos/artigo_2588.pdf.

27. Menezes EA, Tomé ER, Nunes RN, Nunes AP, Freire CC, Torres JC, et al. Extracts of Anacardium occidentale (cashew) pollen in patients with allergic bronchial asthma. J Investig Allergol Clin Immunol. 2002;12(1):25-8.
28. Fernandes L, Mesquita AM. Anacardium occidentale (cashew) pollen allergy in patients with allergic bronchial asthma. J Allergy Clin Immunol. 1995;95(2):501-4

29. Stewart AW, Asher MI, Clayton TO, Crane J, D'Souza W, Ellwood PE, et al. The effect of season-of-response to ISAAC questions about asthma, rhinitis and eczema in children. Int J Epidemiol. 1997;26(1):126-36 